\title{
'A Tart and Bitter Feeling of Jealousy and Remorse': Appraising Subjectivity and Cultural Dimensions in Hong Kong and Indian Readings of an English Poem
}

\author{
Christina A DeCoursey ${ }^{1} \&$ Shilpagauri Ganpule ${ }^{2}$ \\ ${ }^{1}$ Chair, Department of English, American University of Science and Technology, Beirut, Lebanon \\ ${ }^{2}$ Chair, Department of English, RamKrishnaMore College, India \\ Correspondence: Christina A DeCoursey, Chair, Department of English, American University of Science and \\ Technology, Beirut, Lebanon. Tel: 852-2766-7352 E-mail: decourseyca@yahoo.com
}

Received: May 29, 2014

Accepted: June 16, 2014

Online Published: June 18, 2014

doi:10.5430/elr.v3n1p72

URL: http://dx.doi.org/10.5430/elr.v3n1p72

\begin{abstract}
English has become a global language. Chinese and Indian tertiary students comprise a majority of global English users, and a significant proportion of highly-proficient graduates in the knowledge economy. World Englishes authors are included in the curricula of both nations. This study analysed data from 98 Indian and 92 Hong Kong tertiary readers of Tagore's 'The Golden Boat'. Data was analysed using Appraisal analysis to compare subjective attitudes. Appraisal analysis uses computational methods to produce a detailed analysis of attitudes in three systems: emotion, judgment and appreciation. Content analysis was completed, using Hofstede's cultural dimensions, to detail differences between the two groups. Cultural dimensions are a long-standing, validated research paradigm based in psychometric data, and are widely used. Examples of students' comments explore similarities in emotional responses, and generalisations to self and others. The study indicates cultural specificities in the tendency to generalise literature to personal experience, and in specific areas of subjective attitudes. Differences were found in the specific cultural meanings used to explain these, by the two groups. Indian responses realise cultural values stressing overarching philosophical meanings, where Hong Kong responses focus on task orientation, particularly reward. Implications are noted for second-language literary readings, tertiary institutions and graduates.
\end{abstract}

Keywords: Linguistics, Literature, Second-language readers, Appraisal analysis, Cultural dimensions, Meaning construction, World Englishes, Rabindranath Tagore

\section{Introduction}

English has become a global language, with the number of second-language (L2) English users worldwide approaching 2 billion (Graddol, 2007). English-language teachers are now 'mediators between various identities, discourses and worldviews' (Kramsch, 2004, 37). Using literature to teach language is common across global English-language curricula (Banks, 2001). Non-native authors have been writing literature in English for decades (Brutt-Griffler and Samimy 2001). English-language curricula include their works (Candlin and Mercer, 2001). The act of reading literature on the part of World English users is an emerging focus of academic study. There are three reasons for studying Indian and Chinese readings of English literature. First, English is widely taught in both nations (Mair, 2003). Together, they comprise a third of the world's population, educating about 350 million English users, including highly proficient tertiary graduates who contribute disproportionately to the global knowledge economy, who will comprise $40 \%$ of global tertiary graduates by 2020 (UIS, 2008; OECD, 2012). Second, English as a global language will rewrite the academic study of literary texts (Kramsch, 2001). Chinese and Indian L2 readers are now the majority of literary interpreters. Third, given the global realities, scholars must consider how L2 readers construct the meanings of literary texts. These new realities justify analysing Indian and Chinese readers' responses to English literary texts. Reading in an L2 engages language proficiencies and cultural values in different ways than for native speakers (Farstup and Samuels 2002). For teachers, literature persists in L2 teaching because it is felt that literature models authentic language, its themes become shorthand for widely-appreciated insights, and its characters and situations offer understandings of identity, relationships, choices and consequences, opportunities and challenges, and a vast array of human experiences (Stearns, 2004). But the construction of meaning takes place within 
individuals. This paper will explore similarities and differences in the meanings Chinese and Indian literary readers construct, when reading Tagore's poem, The Golden Boat.

The meaning of literary texts is indeterminate. Readers, constructors of meaning, are themselves subjects, conditioned by their own cultures (Ilieva, 1997). They use their cultural commitments when constructing and expressing literary meaning (Smagorinsky, 2001). This paper uses Appraisal analysis to explore Indian and Chinese readers' subjective attitudes, as realised linguistically, in concert with Hofstede's cross-cultural, analysis to explore cultural commitments expressed. Appraisal analysis is a tool allowing a fine-grained analysis of expressions of subjective opinion, now an established method within computational linguistics (Scherer, Schoor and Johnstone, 2001). Because models of the verbalisation of subjectivity are converging in the fields of psychology and linguistics, 'Appraisal theories of emotions have gained widespread acceptance in the field of emotion research' (Kuppens, Van Mechelen, Smits et al., 2007, pp.689). An offshoot of Systemic Functional Linguistics, Appraisal analysis provides detail at the clause and lexical level of definition, which is highly reliable when applied to aggregated textual data (Halliday, 1994). Appraisal analysis is based in the assumption that, when expressing an opinion, people select specific words from the numerous possibilities available (Martin, 1995). Within large textual corpora, patterns may be identified in the expression of specific and highly defined categories of emotion, judgments and appreciations. Subjective opinions, or "Attitude" within SFL parlance, may be understood as finely graduated between negative and positive, and as realising views which may be defined with increasing delicacy (Turney 2002). Attitude can be directly inscribed (for example 'I like this poem') or indirectly invoked ('The man seems to fit with the lonely landscape') (Bednarek, 2006). System networks sort lexicogrammatical choices into hierarchical classes (Traugott, 1995). The Attitude System is divided into three semantic regions: emotion, judgment and appreciation, emotion being foundational to the other two, which express personal feeling 'reworked as propositions' about states of affairs outside ourselves (Martin and White, 2005, pp.45). System networks are articulated into sets, or categories and subcategories, as in Figure 1.

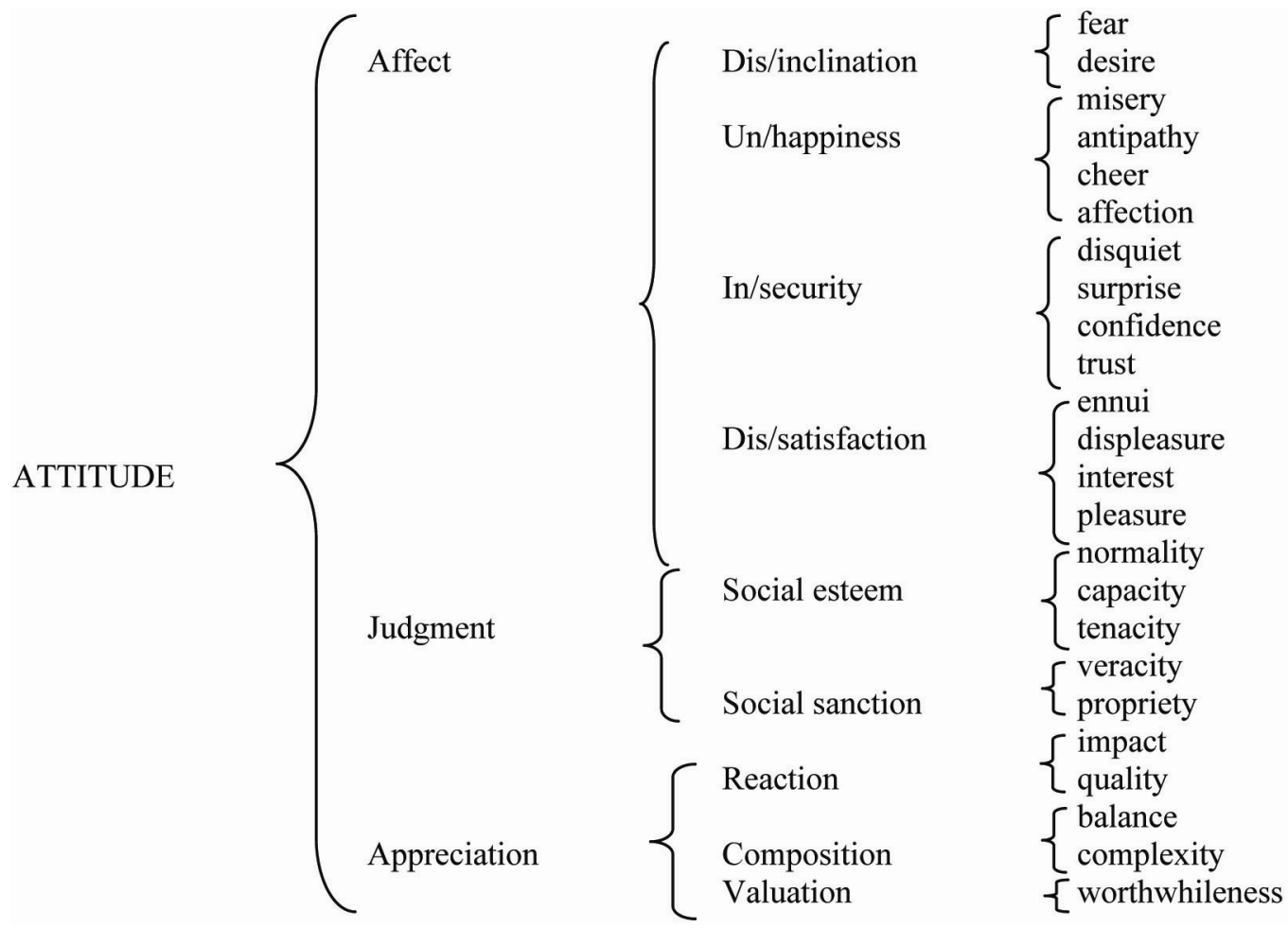

Figure 1. The Attitude System

Appraisal analysis is supported by software. This study used CorpusTool (CT) (O'Donnell, 2008). Automated concordancing is an efficient tool for handling linguistic data (Polanyi and Zaenen, 2006). Computer tagging efficiently identifies regularities within the data, and is viewed as 'robust, result[ing] in good cross-domain performance, and can be easily enhanced with multiple sources of knowledge' (Taboada, Brooke, Tofiloski et al., 2011, pp.36). The Attitude system networks 'are not arbitrarily posited' (Bednarek, 2009, pp.150), but gain validity from their resemblance to psychological models of subjectivity (Oatley, Keltner and Jenkins, 2006). Studies 
assessing the reliability of machine tagging indicate their reliability, especially when complemented by human checking (Wiebe, Wilson and Cardie, 2005).

Sociological research has detailed Chinese and Indian cultural values (Matthews, 2000). Chinese values include solidarity, achieving long-term goals especially in employment (Cheng, 2002). Family is the most important collectivity, with parents and children obligated to the family unit (Inkeles, 1997). Youth must gain employment to ensure care for parents (Shi, 2006). Employment values include self-discipline, persistence and performance of obligations (Zhang and Harwood, 2004). Chinese society views itself as a network of relationships, with politeness and loyalty the keys to success (Tsui and Windsor, 2001). Hierarchy is viewed as enabling social stability and harmony (Yeung, 2000), and dedeference as a pragmatic way to build business relationships (Ding, 2006). Chinese people dislike expressing negative judgments, complaints, or criticism (Cheng, 2000). Indian culture includes greater linguistic and religious diversity (Singh and Sharma, 2009). As individuals maturing in national contexts share experiences, different subgroups share the social values inculcated through the rituals and disciplines of daily life (Van Gorp, 2007; Kashima, 2000; Hofstede, 2001), especially regarding work/wealth, success/failure, authority and justice (Gergen, 2001; Meyer and Jeppersen, 2000). Indian values are also collectivist (Sinha, Vohra, Singal et al.., 2002). Indian values emphasise affective reciprocity and endurance (Walumbwah and Lawler, 2003). Family is the most significant collectivity, organised around eldest males, crediting member attainments in education, income, social position and possessions to his worthiness (Triandis, 1989). Individuals rely on family more than work for security and prestige (Migliore, 2011), valueing conformism over effort, obligation, personal relationships (Chhokar, 2003), deference and compromise (Sinha and Kanungo, 1997). Hierarchy is used to mitigate social stress (Panda and Gupta, 2004). There is a strong commitment to philosophical sources of personal fulfillment (Kumar, 2006).

Hofstede's (1991) Values Survey Model (VSM) furnishes measures for five cultural dimensions, for both Indian and Hong Kong cultures. The VSM generates these from aggregated psychometric data based on extensive questionnaire samples, and are applicable at the country level (Hofstede, 2002). VSM rankings have been derived for 16 countries important for the purposes of international employment norms. VSM studies treat Hong Kong and China as different cultures, due to Hong Kong's different historical development from mainland China, after 200 years of British colonial rule. Higher indices are not better. VSM values for India and Hong Kong are given in Table 1:

Table 1.

\begin{tabular}{lllllll}
\hline & \multicolumn{2}{l}{ Chinese (HK) culture } & \multicolumn{3}{l}{ Indian culture } \\
\hline value & VSM & rank 1984 & rank 2000 & VSM & rank 1984 & rank 2000 \\
long-term orientation & 96 & - & - & 61 & - & - \\
power-distance & 68 & 3 & 7 & 77 & 1 & 2 \\
task orientation & 57 & 7 & 8 & 56 & 8 & 9 \\
uncertainty avoidance & 29 & 1 & 11 & 40 & 4 & 3 \\
individualism & 25 & 15 & 14 & 48 & 12 & 15 \\
\hline
\end{tabular}

Hong Kong and Indian VSM values (Spector, Cooper et al.., 2000, 275-277)

These values indicate that Hong Kong culture places a higher value on long-term orientation (persistence, future status, delayed gratification) than does Indian culture. Indian culture places a higher value on power-distance (acceptance of inequality, hierarchy, obligation) than does Hong Kong, and Hong Kong now gives this less importance than previously. Both cultures have maintained a moderately high value on task-orientation (assertiveness, focus on rewards, belief in gender roles). Indian culture has low where Hong Kong has moderate uncertainty avoidance (tolerance for ambiguity and emotion, preference for social roles), and Hong Kong now values this less than previously. Hong Kong places a low and India a moderate value on individualism (reliance on hierarchy, group loyalty and caring). The VSM data is of course imperfect, but has been continually challenged, and replicated (Søndergaard, 2012). Research suggests that these cultural values are likely to show up in individual expressions of emotions and attitudes (Taras, Kirkman and Steel, 2010, pp.408). Thus, VSM values help to analyse the ways in which Hong Kong and Indian people construct the meaning of literary texts.

\section{Methods}

Participants included 98 Indian tertiary students from Pune, Maharashtra, and 92 Chinese tertiary students from Hong Kong. All were 17 to 22 years old, proficient English-speakers, from across the sciences, social sciences, business and humanities, and enrolled in an undergraduate English literature subject. The text selected was Nobel 
Literature prize-winner Rabindranath Tagore's poem, 'The Golden Boat'. This author is canonical beyond his native India, being among the most widely-anthologised poets in literature texts world-wide (McLeod, 2013). The poem was written in English within the past century, and brief (30 lines), and so is fairly easy for L2 readers to understand. It includes content that connects with the cultural dimensions. In this poem, a young man rests on a bleak riverbank after completing his work of harvesting rice, which we can presume in both cultures would be understood as intended for his family's sustenance. He sees a boat carrying a young woman he admires, wants to go with her, and calls out, offering her his rice harvest. He loads it into her boat, but when he asks her to take him with her, there is no room. The poem ends with him alone on the bleak riverbank again, without the harvest or the young woman. Opportunities to realise cultural dimensions, offered by the lexicogrammatical content of the poem, are shown in Table 2.

Table 2.

\begin{tabular}{ll}
\hline lexicogrammar & cultural dimension \\
\hline sadness, loneliness & uncertainty avoidance-expression of emotion \\
admiring another & power-distance-acceptance of inequality \\
making a request & task orientation-reward, gender roles, and power-distance-obligation \\
giving to another & long-term orientation-persistence, delayed gratification \\
harvesting & power distance-acceptance of inequality, and long-term orientation-persistence, \\
boat loading & future status \\
task orientation-reward, gender roles \\
rejection & uncertainty avoidance-expression of emotion \\
\hline
\end{tabular}

Lexicogrammar relating to the cultural dimensions in Tagore's 'The Golden Boat'

The task was carefully focused and communicated (Connor-Greene 2000). Participants were asked to write a personal response of 100 words. Task instructions asked participants not to narrate plot events, comment on biography of the poet, or include literary critical analysis. Instead, they were asked to focus solely on how they reacted to the poem, and what it meant to them. Personal responses elicit more subjective and less formal commentary than other written academic genres (Bloch, 2007). This created a Hong Kong corpus of 12731 and an Indian corpus of 10348 words. To ensure reliability, data was uploaded to CT. Machine attributions were checked by two trained human taggers with $200+$ hours experience. Finally, the inter-rater reliability was calculated using Cohen's $\kappa$ (Lombard, Snyder-Duch and Bracken, 2002). The percent-overall (p-o) value was 0.911. The free-margin (f-m) value was 0.896 . These indicate strong agreement, not attributable to chance. Content analysis was then completed for both corpuses, to identify cultural values instantiated in responses (Weber, 1985). The unit of analysis was the reflection, broken down to a level between one clause and one sentence, to gain element frequency scores (Carley, 1990). The cultural dimensions were used as an a priori coding frame, employing Hofstede's (2001) content units, applied to synonyms and phrases with similar connotations. Two coders independently obtained frequencies for content units for both corpuses. Inter-coder reliability was again determined using Cohen's kappa (Lombard, Snyder-Duch and Bracken, 2004). The p-o was 0.802 , and the $\mathrm{f}-\mathrm{m}$ was 0.793 , again not attributable to chance.

\section{Results}

Hong Kong readers realised 836 attitudes (for example, 'This poem makes me feel sad'), of which 283 (33.85\%) were negative and $553(66.15 \%)$ were positive. Indian readers realised 612 attitudes about themselves when reading the poem, of which 237 (38.73\%) were negative and 375 (61.27\%) were positive. Attitudinal density in the Hong Kong corpus was 65.67 , in the Indian corpus 59.14 per thousand words. For both cultural groups, five subcategories comprised almost two-thirds of all realisations, as in Figure 4. 
Table 3.

\begin{tabular}{|c|c|c|c|c|c|c|c|c|c|}
\hline & Hong Kong & hinese & & & India & & & & \\
\hline rank & system & category & subcategory & $\%$-ve & rank & system & category & subcategory & $\%$-ve \\
\hline 1 & Affect & Un/happiness & misery & 32.51 & 1 & Affect & Un/Happiness & misery & 37.97 \\
\hline 2 & Appreciation & Composition & complexity & 9.54 & 2 & Judgment & Social esteem & capacity & 10.97 \\
\hline 3 & Judgment & Social esteem & capacity & 9.12 & 3 & Appreciation & Valuation & worthwhileness & 9.70 \\
\hline 4 & Judgment & Social esteem & normality & 8.13 & 4 & Judgment & Social esteem & normality & 7.59 \\
\hline \multirow[t]{2}{*}{5} & Appreciation & Valuation & worthwhileness & 6.36 & 5 & Appreciation & reaction & quality & 6.33 \\
\hline & & & & 65.67 & & & & & 72.56 \\
\hline rank & system & category & subcategory & $\%+v e$ & rank & system & category & subcategory & $\begin{array}{l}\% \\
+\mathrm{ve}\end{array}$ \\
\hline 1 & Appreciation & Reaction & impact & 20.43 & 1 & Appreciation & Valuation & worthwhileness & 19.47 \\
\hline 2 & Judgment & Social esteem & capacity & 12.89 & 2 & Affect & Un/Happiness & cheer & 14.40 \\
\hline 3 & Appreciation & Valuation & worthwhileness & 11.03 & 3 & Appreciation & Reaction & quality & 13.07 \\
\hline 4 & Appreciation & Reaction & quality & 8.86 & 4 & Judgment & Social esteem & capacity & 12.80 \\
\hline \multirow[t]{2}{*}{5} & Affect & Un/Happiness & affection & 8.68 & 5 & Judgment & $\begin{array}{l}\text { Social } \\
\text { sanction }\end{array}$ & propriety & 8.53 \\
\hline & & & & 61.89 & & & & & 68.27 \\
\hline
\end{tabular}

Hong Kong and Indian participants' frequently-realised attitudes

Misery was the most frequently-realised negative attitude, and the only frequently-realised emotion, in both groups. For example, a Hong Kong participant wrote 'I can feel the loneliness from him and the gloomy feelings'. An Indian participant wrote 'I think this is true story of every person. In life we break because of suffering and sorrow.' Negative appreciations of worth were also frequently realised in both groups. A Hong Kong participant generalised the meaning of the young man's effort, thus: 'They are desperate for a meaning in their live so that their empty life can be filled up'. An Indian participant generalised it thus: 'If we lose hope, then we lose everything.' Negative Judgments of social esteem, in the areas of capacity and normality were frequently realised, taking the young man's failure as a model for their own failures. Hong Kong participants wrote: 'This whole poem seems to metaphor one's life. When one strives to achieve for one plan, or a goal, he is not aware of the surroundings ... The person is only able to realize that he is left alone after he achieves that goal' and: 'The sad atmosphere is emphasized in a good way by the misfortune the poet encountered ... from my perspective, this poem may apply to our daily life.' An Indian participant wrote: 'We should not lose the battle of life. The problems are going to come in life.' Negative Appreciations of worth and complexity were also frequently realised, applied either to readers' own experiences, or generalised to humanity (Hong Kong participants: 'Without someone to share with, all that success and achievements mean nothing at all' and 'In today's complicated world, it is easy for us to feel lonely', Indian participant: 'In our life even though we get everything, wealth, property, money, they all are useless if we do not have somebody close who can understand us and stand by us in sun and shower').

Positive appreciations of worth and quality were frequently realised in both groups, again generalised to self or others (Hong Kong participants: 'People should work to make a living, but at the same time, they should stop to enjoy their ability to love and be loved in order to make their lives complete', and: 'they lose the sight of what is important to them such as family, friends, and even self, which I believe is well portrayed', Indian participants: ' The Golden Boat helps us to learn a lesson of life', and 'In the end we cannot take these good things with us'). Similarly, positive Judgments of capacity (Hong Kong participant: 'When the difficulties or problems or sorrows come in life and we are accompanied by our friends, relatives, kins, then it is very easy for us to tackle the problems', Indian participant: 'In life when we are young, we should maintain and foster close relationships which can give us shelter in our old age').

Cultural dimensions are apparent in these comments. Content analysis indicated frequencies for both groups, as in Table 4. 
Table 4.

\begin{tabular}{|c|c|c|c|c|c|}
\hline cultural dimension & content units & Hong Kong & & India & \\
\hline \multirow[t]{3}{*}{ long term orientation } & persistence & 28 & & 46 & \\
\hline & status & 12 & $49=15.46 \%$ & 19 & $86=19.33 \%$ \\
\hline & thrift & 9 & & 21 & \\
\hline \multirow[t]{3}{*}{ power distance } & inequality & 53 & & 13 & \\
\hline & hierarchy & 9 & $73=23.03 \%$ & 3 & $54=12.13 \%$ \\
\hline & obligation & 11 & & 38 & \\
\hline \multirow[t]{3}{*}{ individualism } & hierarchy & 13 & & 8 & \\
\hline & loyalty & 62 & $81=25.55 \%$ & 36 & $73=16.40 \%$ \\
\hline & nurture & 6 & & 29 & \\
\hline \multirow[t]{3}{*}{ task orientation } & assertiveness & 8 & & 7 & \\
\hline & reward & 55 & $99=31.23 \%$ & 43 & $111=24.94 \%$ \\
\hline & gender roles & 36 & & 61 & \\
\hline \multirow[t]{3}{*}{ uncertainty avoidance } & ambiguity & 7 & & 27 & \\
\hline & structure & 5 & $15=4.73 \%$ & 39 & $121=27.19 \%$ \\
\hline & codes & 3 & & 55 & \\
\hline & & 317 & & 445 & \\
\hline
\end{tabular}

Hong Kong and Indian participants' cultural dimensions unit frequencies

Hong Kong participants realised high frequencies in task orientation-rewards (31.23\%), individualism-loyalty $(25.55 \%)$ and power-distance-acceptance of social inequality (23.03\%). Indian participants realised high frequencies in all areas of uncertainty avoidance, especially social codes (27.19\%), task-orientation-gender roles (24.94\%) and long-term orientation-persistence (19.33\%).

\section{Discussion}

The data shows similarities in subjective attitudes realised by the two groups, and in the tendency to generalise meanings to self and others, but differences in the specific cultural meanings used to explain them. Indian responses realise redemptive philosophical meanings, where Hong Kong responses focus on task orientation-reward. These patterns can be seen in some examples.

1 People are selfish in nature, to maximize their benefit.

2 As I grow up, I am forced to realize the importance of money.

3 The paddy harvest is the only property of the narrator, who is possibly a farmer, which symbolizes all the important things a person gives up in courting.

4 The farmer symbolizes people today who are on an endless race of achieving their goals and aspirations such as wealth, fame, and status and the harvested crop could be the 'success' attained.

5 The girl takes it all but not him, whom she views a mere idiot to abandon as she has taken all she can get from him.

Here, Hong Kong readers interpret different elements of the poem as construing the acquisition of wealth as a normal state of affairs. While they perceive that reward entails the sacrifice of some emotional rewards, they view material success as a normal objective, and the young man's generosity as foolish.

By comparison, Indian participants' comments on task-orientation realised gender roles.

6 The real rich man is the one who helps others and works hard for them and give them everything.

7 He wants somebody to accompany him. He wants somebody's companionship, moral support, emotional backing. 
8 In life we always meet ungrateful people like the woman who takes away everything and still does not have the courtesy to take the poet with her.

9 His manhood are far away from him like the trees. He gives away all his earnings.

10 In life people are mean. They take help from us. But they are very ungrateful. They forget our good actions. The lady in the golden boat is such an ungrateful person.

11 She is very selfish, self-centred, heartless and callous.

12 She is like a witch, as she hypnotizes the poet with her melodious voice and sweet smile and makes him give her all his harvest.

In these examples, the male gender role reflects social codes, providing for others, wanting female companionship. As he does not amass wealth, his 'manhood' is questioned. Gender roles interact with social codes, in the focus on courtesy. As the young woman does not fulfil the female gender role, to provide companionship and emotional support, she is criticised. The same focus on personal material gain which Hong Kong participants accepted as normal is here stereotyped as female evil, 'witch', and the young man's gift is attributed to her use of unnatural powers though there is no textual support for this. Indian participants referred to the young woman as 'lady' 135 times, even where they are critical of her, where Hong Kong participants used this word only 23 times, and were far more focused on the young man, in terms of success/failure.

VSM values suggest Hong Kong participants would express higher long-term orientation than Indian. However, Hong Kong participants' comments link persistence and thrift to personal achievement, suggesting greater focus on task-orientation-reward:

13 The space in the golden boat is time that each person is equally given to use.

14 I think that it is not practical if we just sit at home and wait for opportunity to come.

15 We must prioritize the options we have and chose the most valuable ones.

By comparison, Indian participants commented frequently on persistence, interpreting it in interpersonal and philosophical terms:

16 The lady does not have a human face as she comes, sings a song and ruthlessly, goes away alone without taking the poet with her in spite of the poet's persistent request.

17 The problems are always there in life. We should look at them and try to overcome them.

18 According to me while doing any good thing or helping others, back of the mind we should not have the tendency that the person would be helpful to us in future. So while doing good things just carry on don't think about the 'future results'.

These comments valorise persistence in terms of power-distance-obligation, and individualism-caring.

VSM values suggest that Indians would have higher concerns with power-distance than Hong Kong participants. Hong Kong has devalued this, where India has remained near the top ranked countries for this value. Few Hong Kong participants $(7=7.61 \%)$ commented on hierarchy or obligation. Some $(16=17.39 \%)$ expressed acceptance of social inequality, but more $(29=31.52 \%)$ were critical of it, framing these comments as rejections of present-day workplace inequity or past colonialism.

19 The agony to see something shines because of you but without you is shown in this poem, it gives me a tart and bitter feeling of jealousy and remorse.

20 Facing these situations, what we can do is merely strive hard to protect our interest.

21 In our society, there are many other rich men exploiting the other workers. Take the situation in Hong Kong as an example, no matter how hard the employees work, some employers still pay them very low wages and provide them with bad working conditions.

22 In the poem, the farmer represents to the poet, the paddy field which used to be his homeland, his own country, though he is still living on it but it's already occupied by the foreigners and their resources were all snatched by them.

23 The lonely wretch implies Indian people colonized by the Great Britain, and the boat girl represents the greedy colonists. The teeming rain and twisting water are the implications of the hardship and jeopardy of the country. They also forebode the man's coming unfortunate fate. A mysterious girl, singing, steers close to the shore 
which implies the foreign rulers come to India across the oceans. The innocent Indian people expect their 'smile', but they prove to be predators.

24 The man, the embodiment of the Indian people, feels hopeless and alone, because no other country can help them and no national heroes standing out to lead them to fight. This poem satirizes the colonists' selfishness and heartlessness by describing an insatiable boat girl sailing around for looting. The colonists are shaped as a mysterious girl steering a boat. The reason can be that colonists usually embellish their immoral conducts pretending they are amicable communicators of advanced ideas and technologies.

Examples 20 and 21 respond negatively to inequality, framing them as not receiving a legitimate reward (task-orientation). Example 22 generalises the inequality to Hong Kong society. Examples 23, 24 and 25 take the poem as an allegory for the negative qualities of British colonists. Both places have a history of British colonial rule, and colonialism was not part of lectures on this poem in either location. Thus, these comments reflect Hong Kong participants' own views. No Indian participant commented on colonialism or inequality.

Data from this study was consonant with VSM values which indicate that the Indian culture places a higher value on social roles (uncertainty avoidance) than Hong Kong. This received the most frequent comment from Indian participants, particularly the role of the poet:

25 The poet is talking about life. He tries to understand the meaning of life.

26 The poet is very sensitive. He is thinking very deep. He gives an example of rain.

27 The poet is an artist and so he says that the village is painted. The poet's mental agony is represented through the setting of the poem.

28 In this poem the poet says that our life is full of sorrow and suffering. We are alone in this world.

29 Life is a gift of god and this gift is given to human beings. So the poet says that we should always do good things in the beautiful life which god has given us.

30 The poet is telling us about the life cycle pattern. When we are born, we have nothing and when we die, that time also we are empty. We have nothing. The poet tells us that when we come on this earth, we earn a lot of money by a right or wrong path.

The data suggests Indian readers have defined views about the role of the poet as commenting on elements of life and their meaning. Hong Kong participants rarely $(13=14.13 \%)$ mentioned the poet's role. There were 394 uses of 'poet' in the Indian, compared to 62 in the Hong Kong corpus. Hong Kong readers tended to naïvely conflate the poet with the young man: 'There is poet, sad and alone, working on the paddy-field. He has been living in this village and working in this paddy-field for a long time'.

Finally, VSM values indicate that Indian culture is more collectivist than Hong Kong. Indian participants frequently expressed collectivism, with the nature of the solidarity focused on philosophical rather than material gains:

31 We should help others and making others happy should be the motto of our life.

32 The poet is from the farmer's family and he is trying to express the life of villagers which is devoid of happiness.

33 I think the poet is correct. In life we are all alone. We remain alone. Our relatives, our father and mother are not going to be there till the end of our life. The golden boat of life will take everything.

Hong Kong participants, consonant with the VSM values, sometimes expressed loyalty to family as below:

34 It is possible that the poet is not able to leave this place, maybe due to responsibilities for his family or pressure from his landlord.

35 People should work to make a living, but at the same time, they should stop to enjoy their ability to love and be loved.

36 I can sense the loneliness and the idea to leave. There are so many people around but all he can feel is himself in such a huge field space. When a man is getting tired of the dull life in the country, it is true that the strong feeling of being lonely can drive people to leave. Perhaps he is eager to leave and to see the foreign world instead of staying in the paddy field.

37 I prefer sailing a boat by myself to look for opportunities. For example, when I was finding a summer job last year, I put lots of efforts in preparing myself to satisfy the career requirement rather than sending 
an application e-mail only. This really helped me to gain the appreciation of the employer.

These comments valorise individualism.

\section{Conclusion}

As Chinese and Indian English speakers now comprise the majority of readers of English-language literature, their numbers will impact literary interpretation in coming years. This data suggests they share emotional responses, and view literature as generalising personal and social experiences. However, the specific meanings they attribute to emotions and the generalisations made reflect culturally specific values.

As an initial comparative analysis, this study has limitations. As Hong Kong's history diverged from the mainland, data from Chinese readers in the mainland and Taiwan would improve our understanding of contemporary Chinese L2 readers' interpretation. Similarly, due to the diversity of Indian subcultures, data from various groups within Indian society are needed. Also, while Tagore's poem is widely-anthologised, brief literary texts contain few and specific themes. Other texts would elicited other emotions and meanings, helping to determine to what degree meanings attributed are culturally specific. Therefore, these results are provisional, highlighting the need for analysis of L2 readers, especially from these populations, who will comprise most of the world's English users in coming years.

The data suggests that L2 readers of English literature may share emotional responses across cultural groups. Misery was realised three times as often as any other attitude, among both Hong Kong and Indian participants. Still, meanings constructed by participants are better understood to reflect cultural dimensions more than specific subjective attitudes. Indian readers coupled the realisation of specific attitudes with redemptive statements asserting an overarching philosophical reality, consonant with VSM data and with the tendency to find philosophical sources of fulfillment noted in other studies. Hong Kong readers usually expressed negative attitudes without complementary positive assertions, and positive attitudes in relation to task orientation-reward. This is consonant with the VSM data showing high values on reward, but suggests Hong Kong graduates may not accept inequality for themselves. It may also reflect the Chinese tendency to minimise expression of negative comments and emotions (Chen, Cheung et al., 2005). In both groups, Judgments of capacity and complexity were usually applied to the reader, or were generalised to people as a rule. Again, Indian readers applying an overarching philosophy to deficiencies of personal capacity and the challenges of life's complexities, where Hong Kong readers noted the challenge without further comment. Similarly, for positive realisations of quality and worth, Indian readers expressed this as long-term orientation-persistence, and Hong Kong readers as task-orientation-reward. Finally, the data suggests that L2 readers understand English literature as offering generalisable meanings related to one's self and people as a class. L2 readers may anticipate finding such meanings when they read English literature, and it seems clear they use their cultural values to identify such meanings.

We tend to think of literary texts as having meanings that reside in their thematic content and language. We may expect this to be reflected somewhat in L2 readers' comments, regardless of cultural values. Despite cultural nuances, misery was the most-realised response, and reflects the poem. Questions of capacity, complexity, quality and worth are understandably raised, given the young man's disappointment. Neither group realised matters of love relationships, suggesting L2 readers interpretations reflect semantic content.

This study showed how analysing World English literary readings offers understandings about the highly proficient L2 tertiary graduates who will comprise the majority of the global workforce in coming years. This data suggests that Hong Kong graduates value reward more than their Indian counterparts, and are more likely to realise protest than to take it philosophically, as Indian tertiary graduates do. This may reflect the territory's history and its longstanding status as a global financial centre. Indian tertiary graduates may realise redemptive philosophical meanings due to precedents within their culture, and perhaps due to not anticipating reward in the same way as Hong Kong graduates. These two groups, who will contribute greatly to the global knowledge economy in coming years, may have specific strengths and areas of risk, as employees. This finding is of value to fresh graduates, tertiary institutions' views of graduate attributes, and employers.

Finally, this study indicates the value of combining Appraisal with cultural dimensions. Appraisal analysis details subjectivity via frequencies of specific categories of affect, adjudication and appreciation. These can be connected to the cultural content of literary readings. Hofstede's cultural dimensions identify the meanings of subjective attitudes realised. Neither would be sufficient, alone, to detail differences between the two groups. Together they nuanced our understanding of how L2 English users construct literary meaning. 


\section{Acknowledgements}

The authors would like to thank the Honorable Secretary Sandeep Kadam of the Pune District Educational Association, as well as Principal Nitin Ghorpade of RamKrishnaMore College, for their kind support of this project.

\section{References}

Banerjee S. (2006). 'Changing trends of older generations in India: opportunities or obstacles? ICFAI Journal of Consumer Behavior, 1(2), pp.6-15. http://dx.doi.org/10.1108/13527600810914157

Banks JA. (2001). Cultural diversity and education: Foundations, curriculum, and teaching. Boston: Allyn and Bacon. PDF: http://library.mpib-berlin.mpg.de/toc/ze_2006_372.pdf

Bednarek, Monika. (2006). Polyphony in Appraisal: Typological and topological perspectives. Linguistics and the Human Sciences. 3 (2), pp.107-136.

Bednarek, Monika. (2009). Dimensions of evaluation: Cognitive and linguistic perspectives. Pragmatics and Cognition 17 (10, pp.146-175. http://dx.doi.org/10.1075/p\&c.17.1.05bed

Bloch J. (2007). Abdullah's blogging: A generation 1.5 student enters the blogosphere. Language Learning and Technology 11 (2) pp.128-141. URL: http://lt.msu.edu/vol11num2/bloch/default.html

Brutt-Griffler J \& Samimy K. (2001). Transcending the nativeness paradigm. World Englishes, 20, pp.99-106.

Candlin C \& Mercer N. (2001). English language teaching in its social contexts: A reader. London, Routledge. http://dx.doi.org/10.1111/1467-971X.00199

Carley K. (1990). Content analysis. In Asher, R. E (Ed.) The encyclopedia of language and linguistics. Edinburgh, Pergamom Press, pp.725-730.

Chen Silvia, Cheung F, Bond M, \& Leung J. (2005). Decomposing the construct of ambivalence over emotional expression in a Chinese cultural context. European Journal of Personality 19(3), pp.185-204. http://dx.doi.org/10.1002/per.538

Cheng X. (2000). Chinese EFL students' cultures of learning. In Lee C and Littlewood W (Eds.) Culture, Communication and Language Pedagogy, Hong Kong, Hong Kong Baptist University Press, pp.103-116.

Cheng, RHM. (2002). Moral education in Hong Kong: Confucian-parental, Christian-religious and liberal-civic influences. Journal of Moral Education 33 (4), pp.533-551. http://dx.doi.org/10.1080/0305724042000315626

Chhokar JS. (2003). India: Diversity and complexity in action. In Chhokar JS Broadbeck FC and House RJ (Eds), Societal Culture and Leadership in 27 Counties, Thousand Oaks, CA, Sage Publications.

Connor-Greene P. (2000). Making connections: Evaluating the effectiveness of journal writing in enhancing student learning. Teaching of Psychology 27(1), pp.44-46. http://dx.doi.org/10.1207/S15328023TOP2701_10

Ding, DD. (2006). An indirect style in business communication. Journal of Business and Technical Communication, 20(1), pp.87-100. http://dx.doi.org/10.1177/1050651905281051

AE Farstrup \& S Samuels (Eds.). (2002). What Research Has to Say About Reading Instruction. Newark, DE: International Reading Association.

Gergen KJ. (2001). Social construction in context. Thousand Oaks, CA, Sage Publications.

Graddol, David. (2007). English Next British Council, The English Company UK , http://www.britishcouncil.org/learning-research-english-next.pdf accessed September 3, 2012.

Halliday MAK. (1994). An Introduction to Functional Grammar. London, Edward Arnold.

Hofstede G. (1991). Cultures and Organizations: Software of the Mind, McGraw-Hill, London.

Hofstede G. (2001). Culture's Consequences: International Difference in Work-Related Values. Beverley Hills CA, Sage.

Hofstede Geert. (2002). The pitfalls of cross-national survey work: A reply to the article by Spector et al. on the Psychometric properties of the Hofstede Values Survey Module 1994. Applied Psychology 51(1), pp.170-173. http://dx.doi.org/10.1111/1464-0597.084_2

Ilieva R. (2000). Exploring culture in texts designed for use in adult ESL classrooms. TESL Canada Journal 17(2), pp.50-63. PDF: http://files.eric.ed.gov/fulltext/EJ659470.pdf

Inkeles A. (1997). Continuity and change in popular values on the Pacific Rim. USA, Stanford University Press. 
Kashima Y. (2000). 'Recovering Bartlett's social psychology of cultural dynamics. European Journal of Social Psychology, 30(3), pp.383-403. http://web.a.ebscohost.com/ehost/pdfviewer/pdfviewer?sid=07da068a-7da5-44b6-859a-579ca9196806\%40sessi onmgr $4002 \&$ vid $=2 \&$ hid $=4112$

Kramsch C. (2001). Language and Culture. Oxford, Oxford University Press.

Kramsch C. (2004). The language teacher as go-between. Utbildning and Demokrati 13 (3) pp.37-60. PDF: http://www.oru.se/Extern/Forskning/Forskningsmiljoer/HumUS/Utbildning_och_Demokrati/Tidskriften/2004/N r_3/Kramsch.pdf

Kuppens Peter, Van Mechelen I, Smits DJM, De Boeck P \& Ceulemans E. (2007). Individual differences in patterns of appraisal and anger experience. Cognition and Emotion 21 (4) pp.689-713. http://dx.doi.org/10.1080/02699930600859219

Lombard M, Snyder-Duch J \& Bracken C. (2002). Content analysis in mass communication: Assessment and reporting of intercoder reliability. Human Communication Research 28(4) pp.587-604. http://dx.doi.org/10.1111/j.1468-2958.2002.tb00826.x

Lombard M, Snyder-Duch J \& Bracken C. (2004). Practical resources for assessing and reporting intercoder reliability in content analysis research projects. PDF: ils.indiana.edu/faculty/hrosenba/www/Research/methods/lombard_reliability.pdf

Mair C (Ed.). (2003). The politics of English as a world language: New horizons in postcolonial cultural studies. Amsterdam: Rodopi.

Martin R. (1995). Interpersonal meaning, persuasion and public discourse: Packing semiotic punch. Australian Journal of Linguistics 15 (1), pp.33-67. http://dx.doi.org/10.1080/07268609508599515

Martin JR \& White Peter. (2005). The Language of Evaluation: Appraisal in English. New York, Palgrave.

Matthews Barbara. (2000). The Chinese Values Survey: An interpretation of value scales and consideration of some preliminary results. International Education Journal 1(2), pp.117-126. URL: http://hdl.handle.net/2328/3137

Meyer JW, \& Jepperson RL. (2000). The 'actors' of modern society: The cultural construction of social agency. Sociological theory, 18(1), pp.100-120. http://dx.doi.org/10.1111/0735-2751.00090

McLeod, Alan. (2013). Canon of commonwealth literature: Essays in criticism. New Delhi, Sterling Publishers.

Migliore, LA. (2011). Relation between big five personality traits and Hofstede's cultural dimensions: Samples from the USA and India. Cross Cultural Management: An International Journal, 18(1), pp.38-54. http://dx.doi.org/10.1108/13527601111104287

Oatley K, Keltner D \& Jenkins JM. (2006). Understanding Emotions. Blackwell, Oxford.

O'Donnell M. (2008). Demonstration of the UAM CorpusTool for text and image annotation. Proceedings of the ACL-08: HLT Demo Session (Companion Volume) Columbus, Ohio, Association for Computational Linguistics, pp.13-16.

Organization of Economic Cooperation and Development, (2012). Educational indicators in focus' 05. www.oecd.org/edu/50495363.pdf

Panda A., \& Gupta RK. (2004). Mapping cultural diversity within India: A meta-analysis of some recent studies. Global Business Review, 5(1), pp.27-49. http://dx.doi.org/10.1177/097215090400500103

Polanyi L \& Zaenen A. (2006). Computing attitude and affect in text: Theory and applications. Springer, USA.

Scherer KR, Schoor A \& Johnstone T (Eds.). (2001). Appraisal processes in emotion: Theory, methods, research. Canary, Oxford University Press.

Shi L. (2006). The successors to Confucianism or a new generation? A questionnaire study on Chinese students' culture of learning English. Language, Culture and Curriculum, 19(1), pp.122-147. http://dx.doi.org/10.1080/07908310608668758

Sinha, JBP \& Kanungo, RN. (1997), Context sensitivity and balancing in Indian organisational behaviour. International Journal of Psychology, 32(2), pp.93-105. http://dx.doi.org/10.1080/002075997400890 
Singh DP \& Sharma MK. (2009). Unfolding the Indian cultural mosaic: a cross-cultural study of four regional cultures. International Journal of Indian Culture and Business Management, 2(3), pp.247-267. http://dx.doi.org/10.1504/IJICBM.2009.023547

Sinha JBP, Vohra N, Singhal S, Sinha RBN \& Ushashree S. (2002). Normative Predictions of Collectivist-Individualist Intentions and Behaviour of Indians. International Journal of Psychology 37(5), pp.309-19. http://dx.doi.org/10.1080/00207590244000124

Smagorinsky P. (2001). If meaning is constructed, what is it made from? Toward a cultural theory of reading. Review of Educational Research 71 (1), pp.133-169. http://dx.doi.org/10.3102/00346543071001133

Søndergaard, Mikael. (2012). Hofstede's Consequences: A study of reviews, citations and replications. Organizational Studies 15(3), pp.447-456. http://dx.doi.org/10.1177/017084069401500307

Spector P, Cooper CL, \& Sparks K. (2000). An international study of the psychometric properties of the Hofstede Values Survey Module 1984: A comparison of individual and country/province level results. Applied Psychology 50(2), pp.269-281. http://dx.doi.org/10.1002/job.118

Stearns PN. (2004). Teaching Culture. Washington, D.C., Association of American Colleges and Universities.

Taboada M, Brooke J, Tofiloski M, Voll K, \& Stede M. (2011). 'Lexicon-based methods for sentiment analysis. Computational Linguistics, 1 (1), pp.1-42. http://dx.doi.org/10.1162/COLI_a_00049

Taras V, Kirkman B \& Steel P. (2010). Examining the impact of Culture's Consequences: A three-decade, multilevel, meta-analytic review of Hofstede's Cultural Value dimensions. Journal of Applied Psychology 95(3), pp.405-439. http://dx.doi.org/10.1037/a0018938

Traugott EC. ( 1995). Subjectification in grammaticalisation. In Stein, D, and Wrights, S, (eds.) Subjectivity and Subjectivisation, Linguistic Perspectives. Cambridge, Cambridge University Press , pp.31-54. http://dx.doi.org/10.1017/CBO9780511554469.003

Triandis HC. (1989). The self and social behavior in differing cultural contexts. Psychological Review, 96(3), pp.506-20. http://dx.doi.org/10.1037/0033-295X.96.3.506

Tsui J \& Windsor C. (2001). Some cross cultural evidence on ethical reasoning. Journal of Business Ethics, 31, pp.143-150. http://dx.doi.org/10.1023/A:1010727320265

Turney, P.D. (2002). "Thumbs up or thumbs down? Semantic orientation applied to unsupervised classification of reviews" Proceedings of the $40^{\text {th }}$ Annual Meeting of the Association for Computational Linguistics, pp. 417-424, Philaldephia, PA, USA. http://dx.doi.org/10.3115/1073083.1073153

UNESCO Institute for Statistics. (2008). Global education digest 2008: Comparing education statistics across the world. Montreal, UIS.

Van Gorp B. (2007). The constructionist approach to framing: Bringing culture back in. Journal of communication, 57(1), pp.60-78. http://dx.doi.org/10.1111/j.0021-9916.2007.00329.x

Walumbwa FO \& Lawler JJ. (2003). Building effective organizations: transformational leadership, collectivist orientation, work-related attitudes and withdrawal behaviours in three emerging economies. International Journal of Human Resource Management, 14(7), pp.1083-1101. http://dx.doi.org/10.1080/0958519032000114219

Weber R. (1985). Basic content analysis. London, Sage Publications.

Wiebe J, Wilson T \& Cardie C. (2005). Annotating expressions of opinions and emotions in language. Language Resources and Evaluation 39 (2-3), pp.165-210. http://dx.doi.org/10.1007/s10579-005-7880-9

Yeung W. (2000). Limits to the growth of family-owned business? The case of Chinese transnational corporations from Hong Kong. Family Business Review 13 (1) 55-70. http://dx.doi.org/10.1111/j.1741-6248.2000.00055.x

Zhang Y, \& Harwood J. (2004). Modernization and tradition in an age of globalization: Cultural values in Chinese television commercials. Journal of Communication 54, pp.156-172. http://dx.doi.org/10.1111/j.1460-2466.2004.tb02619.x 